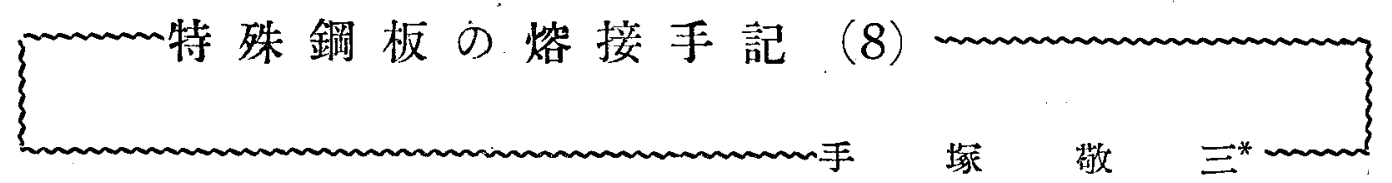

「てにが防彈鋼板なんだからほんのわすかな事にる、洁

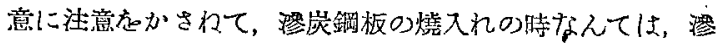

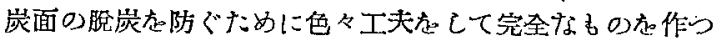

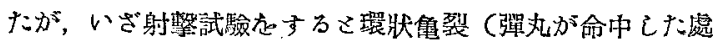
な中心にして波紋萠に，石垣のような模樣に出る割れうが

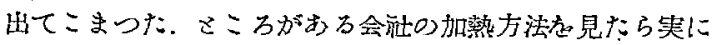
無雜作で，むれでは脫炭が拉こつて豤い䊅果は得られない だろうこ思つていたら，射慗の結果は何でもない，早速や

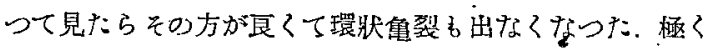
表面は脱宸してろ方が良いて氣がついた」て言いながら非 常にうれしい苦労のように眼元に笑ないつばい浮べながら の話だつた。

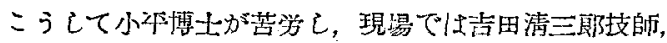

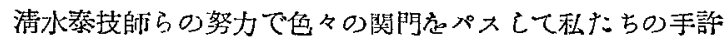
に邆り属けられるのだ。しかしこんな問題があった。私は 早速ダグラス Dc 3型でエヤーガールの親切さ走满契しな

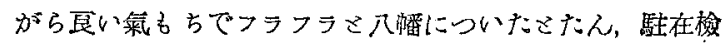
查官のごら声におる゙かされて，ハツ己氣在取り直した。

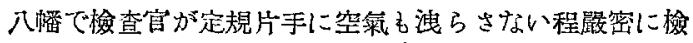
查して出した行らな板が東京に來方さ反繰り反つていて便 いものにならないのだ：れは前にる迅へた雪䧗正の時の ニンーマチックンンマーの断面程が大きすぎて，力の澄透. が不足で東京に來る旅行中に鋼板の莱がゆるんでとまうた めだ，田舍の嚴重な親父の監督の眼が屆がない東京遊学の ごら息子みたいな話だが，硬い硬い焅入れされた特珠鉬板 でさえたががゅるんだて言うわけ。

大切な人栐の御于息にふチなつけたんだから必死で原因

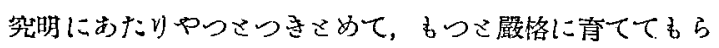

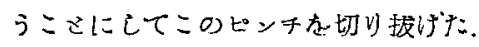

これらのここについてはその後邽大の上田太郎搏士の「

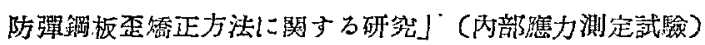
報告が昭和18年11月 1 日に提出され，さらに研究が進めら れ「製造工場に於て制れ防止に関して探るべき手段および 製造工程中特に留意す心゙き事項」そ宣う大変长い題名の報 告青になつて昭和20年 1 月20日に発表されたそのきつかけ な作つた。

このううに熔接から問題は板にうつつて,これには今病

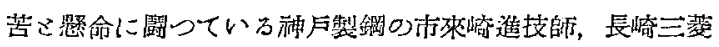

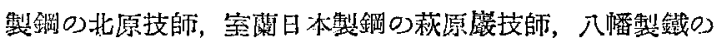

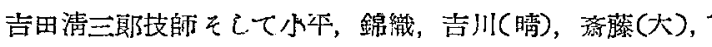

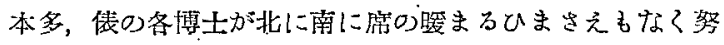

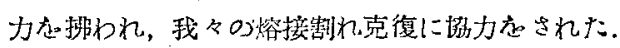

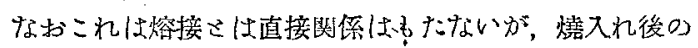

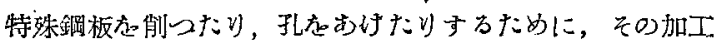

方法の研究も同時に行われたが，木下族雄博士さ私はその

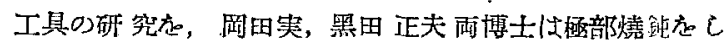
て加工寸方研究定したが、このデーターはそのままデニー コール鋼等の加工に刑用されるのではないかて考えてい ๖.

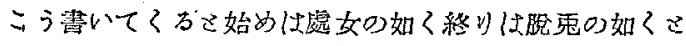
誰もが感じらであるうが，それにはこんなわけがする。

\section{6. セミコロン.,}

セミコロンは切れても切れないとると……芒言う誰がの 話走思い出したりりでもないが，熔接学会誌は前号飞この

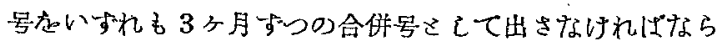
なくなつたそそれは每㝍会告で挀えているように会費の集 りが会誌の発行に件わないことが主なる原因なのだ。

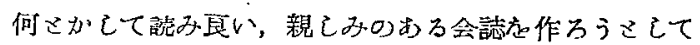
終戰以來私たち古は色々苦労危して來たがやや勒道に乘りか けたをころで,インフレの昂進，郵稅の值上げを次から次

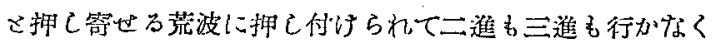
なつてしまつた。

、私は多くの先翼や学者，技街者加戝時中に行つた偉大な 研究が軍の極秘のために埋るれ，人に知られす消えて行く こを起悲しんで，幸にしてこの仕事に始めからたずさつ ていなので，記錄に止めておきたいて思い，成可く多くの 人たちに知つてるらうに生堅苦しい公式的な書き方でな

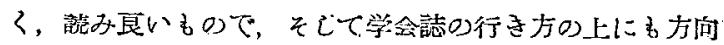
性㤂つけょうこして，想うねらいの生分にもならぬ笔致で。 㿠けて來たが，今申に上げたような次第で学会誌にはその ゆさりるなくなつたわけた゚.

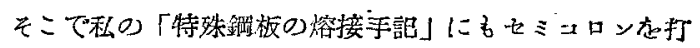
たなりれれ゙ならなくなつた次第. 多くの先留諸兄の大きな 桨績に対已甚だ残念々は思う加，今度出來万日本熔接協会 機会誌「熔接界」の誌上にでも出來たら書导続けたいを思 つている.

こ汃これまでに書きなぐつて來たこさによって，特珠

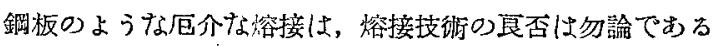

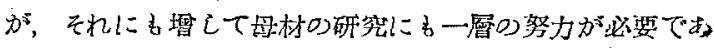
るこされおばかげ乍らお傅えするここが出來たて思う。 して熔接後のごんな精密な檢查よりる大切なこるは聺接前

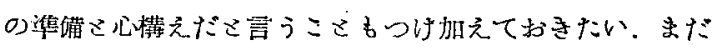
そこまで発展しなからななめに発展し得なかった研究者, 日立製作所の島野秀蜼技師，三浦春信技師，田中䁷，柴田

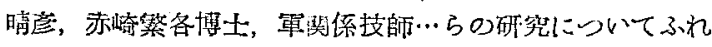

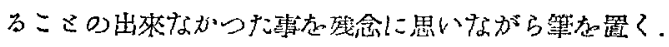

$$
\text { 一⿻上丨- }
$$

(移划)

\footnotetext{
*正 貴 日本熔接協念常任理事
} 